into the 18th century and beyond. While a focus on South Carolina is entirely legitimate, the sleight of hand that allows the experience of that part of the world to stand, unmarked, for 'New World slavery' is almost as problematic an obfuscation as is the practice, which Morgan rightly criticizes and brilliantly undoes, of allowing 'slave' to equal 'man'.

Diana Paton

doi:10.1057/palgrave.fr. 9400268

\title{
Camp all-American, Hanoi Jane, and the high-and-tight: gender, folklore, and changing military culture
}

Carol Burke; Beacon Press, Boston, USA, 2004, ISBN 0-8070-4660-4 (Hbk)

Carol Burke begins her lengthily titled book with the tale of her stint as a cadet at Fort Bragg, the home of the 82nd Airborne Division, the largest parachute force in the world and a sort of mini-army in its own domain, complete with pilots, infantry, artillery, and armour soldiers as well as parachute-trained cooks, mechanics, radiomen, electricians, photojournalists, and computer operators (pp. 2-3). She vividly describes putting on a uniform, rappelling down wooden towers, squeezing into tanks, firing a howitzer, and going along with a squad of cadets ordered to take a bunker at an artillery range - all exercises that were designed to produce the kind of 'warrior leaders' that 'all-American soldiers' are supposed to become. Burke excels where her impeccable eye (and ear) for detail is employed, particularly in her discussions of clothes, speech and ritual, but overall the book is not a conventional ethnography.

Instead, Camp All-American Hanoi Jane, and the High-and-Tight: Gender, Folklore, and Changing Military Culture is a carefully assembled series of approaches to the analysis of the politics of gender in the military and, more precisely, the US Naval Academy. One can read the book just as fruitfully by reading the chapters independently as by reading the book as a whole. Oscillating back and forth from a folklorist's careful descriptions of everyday activities, jokes, marching chants, and initiation rituals to a journalist's sharp investigative accounts of controversies, Burke sheds light on the following issues: the kinds of transformations soldiers undergo during basic training (Chapter 3 ); the making of military masculinities within a strategic framework that declares that men must be made and, at the same time, that insists recruits must be men to begin with (Chapter 4); the enormous difficulties of harmonizing initiation rites that seem to 
resemble male puberty rites of tribal cultures with the necessity of instilling, maintaining, and effectively applying an understanding of other cultures in current-day missions other than war (Chapter 5); the varied meanings of military uniforms (Chapter 6); the intricacies of military speech (Chapter 7); a controversy that leads to the suicide of a then-chief of naval operations and highest-ranking officer in the navy (Chapter 8); the treatment of prisoners of war (Chapter 9); the continuing strategic demonization of Jane Fonda (Chapter 10); and the kinds of impact that 'digital war' might have on the place of masculine exclusivity (Chapter 11).

Throughout this series of close-ups, Burke forcefully suggests that the gender politics of the US Navy Academy works not only against the integration of women but also against the efficiency and adaptability of the force. American military culture appears as 'fundamentally and dangerously cultic' (p. 13). But Burke also successfully argues that there is no detectable, reasoned link between the warrior and the professional soldier and the kinds of exclusivist, masculinist rituals the military holds on to despite the dramatically changing challenges of new operations other than war and technological advances; and she reminds us that the current-day commander is more likely to be a bureaucrat and manager than a warrior.

In some places (e.g., Chapter 8), her journalistic talents lead her down more investigative avenues of minutiae and one loses a clear vision of the larger framework, but Burke's feminist analysis of the multifold ways by which military rituals continue to exclude women and marginalize female service members is subtle and convincing throughout. Fervent readers of scholarship on the armed forces might have wished for a more layered contextualization of the US Navy Academy and the navy within the armed forces in the US more generally. Burke's analysis, however, is fresh and focused and thus productively complements adjacent scholarship on gender issues within and around the military by political scientists such as Cynthia Enloe or Mary Katzenstein.

Camp All-American is an important contribution to the social scientific study of the armed forces, military-societal relations, and issues of gender and violence, and it also deserves to be read by those brave folklorists who don't shy away from new sites of inquiry. Non-academic readers will find it accessible and a welcome contribution to ongoing debates about the establishment of gender equity, the adjustment to the new demands of military officers' careers, and the new challenges military personnel face in the increasing number of national and international operations other than war. 